\title{
Synthesis and Characterization of New Orange-Red Light-Emitting PPV Derivatives with Bulky Cyclohexyl Groups ${ }^{*}$
}

\author{
Seung Won Ko, Byung-Jun Jung, Nam Sung Cho, and Hong-Ku Shim \\ Center for ithanced Finctional Polwers. Deparment of Chemistry and School of Holecular Science (BK2I),

 \\ Receivedilpril 11, 2002
}

\begin{abstract}
A series of 2.5-dialkoxy substituted poly(l.t-phenylenevinylene) derivatives containing a rigid and bulky cyclohextyl group in the side chain. poly[2-(7-cyclohexylheptyloxy)-5-butoxy-1.4-phenylenevinylene] (PBCyHpPV), Poly[2-(6-cyclohexylmethoxy hexyloxy)-5-butoxy-1.4-phenyleneviny lene] (PBCyHxPV). Poly[2.5-di-(6-cyclohexylmethoxy-hexyloxy)-1,4-phenyleneviny lene] (PDCyHxPV) were synthesized vic the Gilch polymerization. The synthesized poly mers were soluble in common organic solvents and showed good themal stability up to $370^{\circ} \mathrm{C}$. The maximum absorption of PBCyHpPV. PBCyHxPV and PDCyHxPV as thin films was at $513 \mathrm{mml} .515 \mathrm{lum} .511 \mathrm{lum}$. respectively. Photoluminescence maximum enission of above poly mers appeared at $590 \mathrm{~mm} .597 \mathrm{~mm} .590 \mathrm{~mm}$ respectively. The electroluminescence (EL) maxima of the polymers appeared around 585-590 $\mathrm{lm}$, and also showed another shoulder around $630 \mathrm{~mm}$ strongly. PDCyHxP showed the highest EL efficiency and EL power than those of other polymers due to the dilution effect of the two rigid and bulky cyclohexyl groups.
\end{abstract}

Key Words : Electroluminescence. Polỵ(p-pheny lenevingylenc). Cyclohexy]

\section{Introduction}

Since the discovery of electrolumimescence (EL) from poly ( $p$-phenylenevinglene) (PPV). ${ }^{\prime}$ PPV and its derivatives have been extensively studied due to their potential applications as emissive layers in light-emitting diodes (LED)s. EL devices based on organic thin layers are of great interest because of their possible application as large-area lightemitting displays which are operative at low driving voltage. good processibility: fast response time and color tumability over the fill visible range by control of the HOMO-LUMO energy band gap of the emissive layer. ${ }^{4-12}$ However. the final conjugated PPV is insoluble and infusible, so that the processibility is very poor. ${ }^{13-15}$ Bram and Heeger er $\mathrm{cl}^{16-18}$ have reported that they used a soluble PPV derivative with bulky alkoxy side group. poly [2-methoxy-5-(2-ethylhexyloxy)-1.4-pheny lenevinglenel (MEH-PPV), as an emissive layer and used lower work function metal, particularly calcium (Ca), as an electron injecting contact. Since MEHPPV was synthesized many researching groups tried to synthesize the PPV derivatives with dialkoxy substituents for enhancement of the quantum efficiency and solubility. The choice of substituents is allowing solubility and enhancing the EL quantum efficiency. Yoshino ef $\alpha l^{19.21)}$ reported the increment of PL and EL efficiency as increasing the side chain length of light-emitting polythiophene and PPV. This may imply that conjugated EL polymers with long interchain distance due to the long alkyl side chain can reach high

${ }^{\dagger}$ Dedieated with admiration and respecl to Protessor Sang Chul Shim in honor of his scientilic achievements.

"To whom correspondence should be addressed. Phone: +82-42869-2827, Fax: +82-42-869-2810, F-mai]: ]ksinm àmail.kajst.ackr
PL and EL efficiencies caused by confinement of excitons on a main chain and preventing exciton-exciton collisions in the alkyl side chain. A cyclohexyl side chain was adopted firstly in polythiophene as a bulky substituent to achieve spectral blue shift due to steric hindrance ${ }^{21.22}$ For the case of PPVs, Jang et $\mathrm{al}^{2}{ }^{23}$ reported that the dialkoxy substituted PPV derivative containing a rigid and bulky cyclohexyl group in the side chain, poly[2-(5-cyclohexy Imethoxypentoxy $)-5$ methoxy-1.4-phenylenevinylene] (PMCYHPV), shoved good solubility in common organic solvents and about 6 fold higher EL external quantum efficiency than that of $\mathrm{MEH}$ PPV with almost the same operation voltage and EL color. In the present study. we report the synthesis of three new PPV derivatives containing a cyclohexyl group in the side chain: poly [2-(6-cyclohexy lmethoxy hexyloxy)-5-butoxy -1.4-phenylenerinylene] (PBCyHxPV). poly 2.5-di-(6-cyclohexyl methoxy hexylosy)-1,4-phenylenevinylenel (PDCyHxPV), poly[2(7-cyclohexy heptyloxy)-5-butoxy - 1.4-pheny lenevinylene] (PBCyHpPV). In addition, we investigate the effect of the cyclohexyl group on the physical and electrochennical properties of above three polymers, as well as the performance of these polymers as emissive layers in LEDs.

\section{Experimental Section}

Instrumentation. NMR spectra were recorded using a Bruker AVANCE 400 spectrometer with tetrantetly lsilame as the intemal reference. The number and weight average molecular weights of polymers were determined by gel permeation chromatography (GPC) analysis oll a Waters GPC-150C instrument. using THF as eluent and polys sty rene as standard. TGA was performed under nitrogen atnıosphere at a heating rate of $10^{\circ} \mathrm{C} / \mathrm{min}$ with a DuPont 9900 analy zer. 
UV-r isible and photoluminescence spectra were measured using a Jasco V-530 UV/ is spectrometer and a Spex Fluorolog-3 spectrofluorometer respectively. The configuration of the EL derice was ITO/PEDOT/polymer/LiF/Al. The PEDOT Ipoly (styrenesulfonate)-doped poly (3.4-ethylenedioxylhiophene)j employed as the hole-injection laver was spin coated onto preclcancd ITO/glass substrate at a spin speed of $2500 \mathrm{rpm}$ for $40 \mathrm{~s}$. Thin polymer films with a thickness of approximately $100 \mathrm{~nm}$ were then spin coated onto the PEDOT layer from a $0.5 \mathrm{w} \%$ polymer solution in chloroform. LiF and $\mathrm{Al}$ were deposited onto the polymer films using the vacuum cyaporation method at a pressure of $10^{-i}$ Torr. Elcctroluminescence spectra were measured with a Minolia CS-1000). The current/voliage and luminescence/ voltage characteristics were measured using a currenv voltage source (Keithley 238) and a luminescence detector (Minolta LS-100). Cyclic voltammetry was performed on an AUTOLAB/PGSTAT12 with a threc-clectrode cell in a solution of $\mathrm{Bu}_{4} \mathrm{NBF}_{4}(0.10 \mathrm{M})$ in acctonitrile al a scan rate of $50 \mathrm{mV} / \mathrm{s}$. All measurements were performed at room temperature under ambicnt atmosphere.

Materials. All reagents were purchased from Aldrich and used without further purification. PEDOT was purchased from Baycr. Tetrahydrofuran (THF) was dricd over sodium/ benzoplicnone.

7-Cyclohexylheptyl bromide (1). A $2 \mathrm{~mL}$ ol (bromomethyl)cyclohexane $(35.6 \mathrm{~g} .0 .2 \mathrm{~mol})$ was added to a suspension containing $\mathrm{Mg}(4.7 \mathrm{~g} .0 .2 \mathrm{~mol})$ in THF (40 mL). After stirring for 5 minutes. the mixture started to reflux. The rest of (bromomethyl) cyclohexanc was then added to the mixture in such a rate to maintain the relluxing. The resulting Grignard rcagent was transferred into an addition funnel and added dropwisc into a mixture containing an excess of 1.6-dibromohexanc (6l g. $0.25 \mathrm{~mol}$ ). $\mathrm{Li}_{2} \mathrm{CuCl}_{4}(25$ $\mathrm{mL}$ of ( $0.1 \mathrm{M}$ THF solution. $2.5 \mathrm{mmol}$ ). and $40 \mathrm{~mL}$ of $\mathrm{THF}$ at 0 "C. The resulting mixture was stirred overnight at room temperature and then poured into water. The mixture was extracted with methylene cliloride. Pure product was obtained by vacuum distillation. The product yield was $42 \% .{ }^{1} \mathrm{H}$ NMR (C.DCl. ppm) $\delta 3.3(\mathrm{t} .2 \mathrm{H}), 1.8(\mathrm{~m} .2 \mathrm{H}), 1.6(\mathrm{~m} .5 \mathrm{H})$. $1.5-1.0(\mathrm{~m} .14 \mathrm{H}), 0.8(\mathrm{~m}, 2 \mathrm{H})$.

(6-Bromo-hexyloxymethyl)cyclohexane (2). Cyclohexylmethanol (46 g. $0.4 \mathrm{~mol}$ ) was dissolved in $300 \mathrm{~mL}$ of anhydrous tetralıydrofuran, and $60 \mathrm{wt} \%$ sodium lydride $(24.3 \mathrm{~g} .0 .6 \mathrm{~mol})$ was added to the solution at room temperature. And then the solution was refluxed under nitrogen atmosphere. After 4 hours, 1,6-dibromohexane (152 g. 0.6 mol) was slowly added to the solution and the solution was refluxed for 24 hours. The reaction was quenched by addition of water, and then extracted with methylene chloride. The colorless liquid product was obtained by vacuum distillation. The product yield was $45 \%$. 'H-NMR $\left(\mathrm{CDCl}_{3}, \mathrm{ppm}\right) \delta 3.3(\mathrm{~m} .4 \mathrm{H}) .3 .1(\mathrm{~d}, 2 \mathrm{H}), 1.8(\mathrm{~m}, 2 \mathrm{H}), 1.7-$ $1.2(\mathrm{~m}, 15 \mathrm{H}), 0.8(\mathrm{~m}, 2 \mathrm{H})$.

1-(7-Cyclohexylheptyloxy)-4-butoxybenzene (3). Compound 3 was prepared by reacting $16.7 \mathrm{~g}(0.1 \mathrm{~mol})$ of $4-$ butoxyphenol. $26.2 \mathrm{~g}(0.1 \mathrm{~mol})$ of compound 1 and $7.3 \mathrm{~g}$
(0. $11 \mathrm{~mol}$ ) of potassium hydroxide in $200 \mathrm{~mL}$ methanol. The reaction solution was heated at $80{ }^{\circ} \mathrm{C}$ for 24 hours. The resulting mixture was extracted with methylene chloride and dried over anhydrous magnesium sullate. The pure white solid product was acquired by precipitated lrom methanol. The produce yicld was $80 \%$. ${ }^{j} \mathrm{H}-\mathrm{NMR}\left(\mathrm{CDCl}_{3}\right.$. ppm) $\delta 6.8$ (s. 4H). $3.9(\mathrm{~m}, 4 \mathrm{H}), 1.7(\mathrm{~m}, \mathrm{loH}), 1.5-1.3(\mathrm{~m}, \mathrm{l} 5 \mathrm{H}), \mathrm{l} .0-(\mathrm{)})$ (m, 5H).

1 - Butoxy-4-(6-cychlohexylmethoxy-hexyloxy)-benzenc (4). Compound + was prepared lollowing the procedure described above for compound 3 . The product yicld was $83 \%$. 'H-NMR ( $\left.\mathrm{CDCl}_{3}, \mathrm{ppm}\right) \delta 6.8(\mathrm{~s}, 4 \mathrm{H}) .3 .8(\mathrm{t},+\mathrm{H}), 3.2$ (t. 2H). 3.1 (d. 2H). 1.8-().8(m. 25H).

1,4-Bis-(6-cyclohexylmethoxy-hexyloxy)-benzene (5). Compound 5 was prepared lollowing the procedure described above for compound 3. starting from hydroquinone. The product yicld was $63 \%$. 'H-NMR $\left(\mathrm{CDCl}_{3}\right.$, ppm): $\delta 6.8$ (s. 4H). $3.8(\mathrm{l} .4 \mathrm{H}) .3 .3(\mathrm{l} .4 \mathrm{H}) .3 .1$ (d. $4 \mathrm{H}) .1 .8-(0.8(\mathrm{~m} .38 \mathrm{H})$

1,4-Bisbromomethỵl-2-butoxy-5-(7-cyclohexyl-heptyloxy)-benzenc (6). To a solution of compound 3 (17.3 g. 50 mmol) and paralormaldchyde $(7.5 \mathrm{~g} .250 \mathrm{mmol})$ in $100 \mathrm{~mL}$ of acctic acid was added dropwise $20 \mathrm{~mL}$ of $30 \mathrm{w} \% \mathrm{HBr}$ solution in acctic acid at room temperature. A nitrogen atmosphere was established followed by heating the mixture to $70^{\circ} \mathrm{C}$ for 4 hours. Alter allowing the mixture to cool to ambient temperature. the mixture was diluted with chloroform followed by cxtraction with water and $\mathrm{NaHCO}_{3}$ (aq). The chloroform solution was dricd over anhydrous magnesium sulfate followed by removal of the solyent under reduced pressurc. Purification by recrystallization from hexanc alTorded 2l g $(80 \%)$ of compound 6. 'H-NMR (CDCl $\mathrm{Cpm}_{3}$ ): $\delta 6.9$ (s. $\left.2 \mathrm{H}\right) .4 .6(\mathrm{~s} .4 \mathrm{H}) .4 .0(\mathrm{~m} .4 \mathrm{H}) .1 .7(\mathrm{~m}$. $\mathrm{loH}) .1 .5-1.3(\mathrm{~m} .15 \mathrm{H}) .1 .0-0.8(\mathrm{~m} .5 \mathrm{H})$.

1,4-Bisbromomethyl-2-butoxy-5-(6-cyclohexylmethoxyhexyloxy)-benzene (7). To a solution of compound $4(7.0 \mathrm{~g}$. $20 \mathrm{mmol}$ ) and paraformaldehy de (3.0 $\mathrm{g}$. $100 \mathrm{mmol}$ ) in $30 \mathrm{~mL}$ of acclic acid was added dropwise $10 \mathrm{~mL}$ of $30 \mathrm{w} \% \mathrm{HBr}$ solution in acetic acid at room temperature. The following experimental procedures were the same as above described. The product yield was $62 \%(6.8 \mathrm{~g})$. ${ }^{1} \mathrm{H}-\mathrm{NMR}\left(\mathrm{CDCl}_{3 .} \mathrm{ppnu}\right)$ : $\delta 6.8$ (s. $2 \mathrm{H}), 4.5$ (s. $4 \mathrm{H}) .3 .9(\mathrm{t} .4 \mathrm{H}) .3 .4(\mathrm{t} .2 \mathrm{H}) .3 .2(\mathrm{~d} .2 \mathrm{H})$. $1.8-0.8(\mathrm{ml} .26 \mathrm{H})$.

1,4-Bisbromomethyl-2,5-bis(6-cyclohexylmethoxy-hexyloxy)-benzene (8). To a solution of compound $5(6.0 \mathrm{~g} .12$ $\mathrm{mmol}$ ) and paraformaldehyde $(2.0 \mathrm{~g} .67 \mathrm{munol})$ in $30 \mathrm{nuL}$ of acetic acid was added dropwise $7 \mathrm{~mL}$ of $30 \mathrm{wt} \% \mathrm{HBr}$ solution in acetic acid at roon temperature. The following experimental procedures were the sante as above described. The product y ield was $59 \%(4.9 \mathrm{~g})$. ${ }^{1} \mathrm{H}-\mathrm{NMR}\left(\mathrm{CDCl}_{3 .} \mathrm{ppnl}\right)$ : $\delta 6.8$ (s. $2 \mathrm{H}), 4.6(\mathrm{~s} .4 \mathrm{H}) .3 .9(\mathrm{t} .4 \mathrm{H}) .3 .4(\mathrm{t} .4 \mathrm{H}) .3 .1$ (d. $4 \mathrm{H})$. $1.8-0.8(\mathrm{~m}, 38 \mathrm{H})$.

Poly|2-(7-cyclohexyl-heptyloxy)-5-hutoxy-1,4-ןhenylenevinylenel (PBCyHpPV). The compound 6 (1.06 g. 2 mmol) was dissolved in $80 \mathrm{~mL}$ of anhydrous tetrahydrofuran. and $12 \mathrm{~mL}$ of potassium $t$-butoxide ( $1 \mathrm{M}$ in THF) in $60 \mathrm{~mL}$ anhydrous tetralyydrofuran was slowly added dropwise to the solution under nitrogen atmosphere. The reaction 


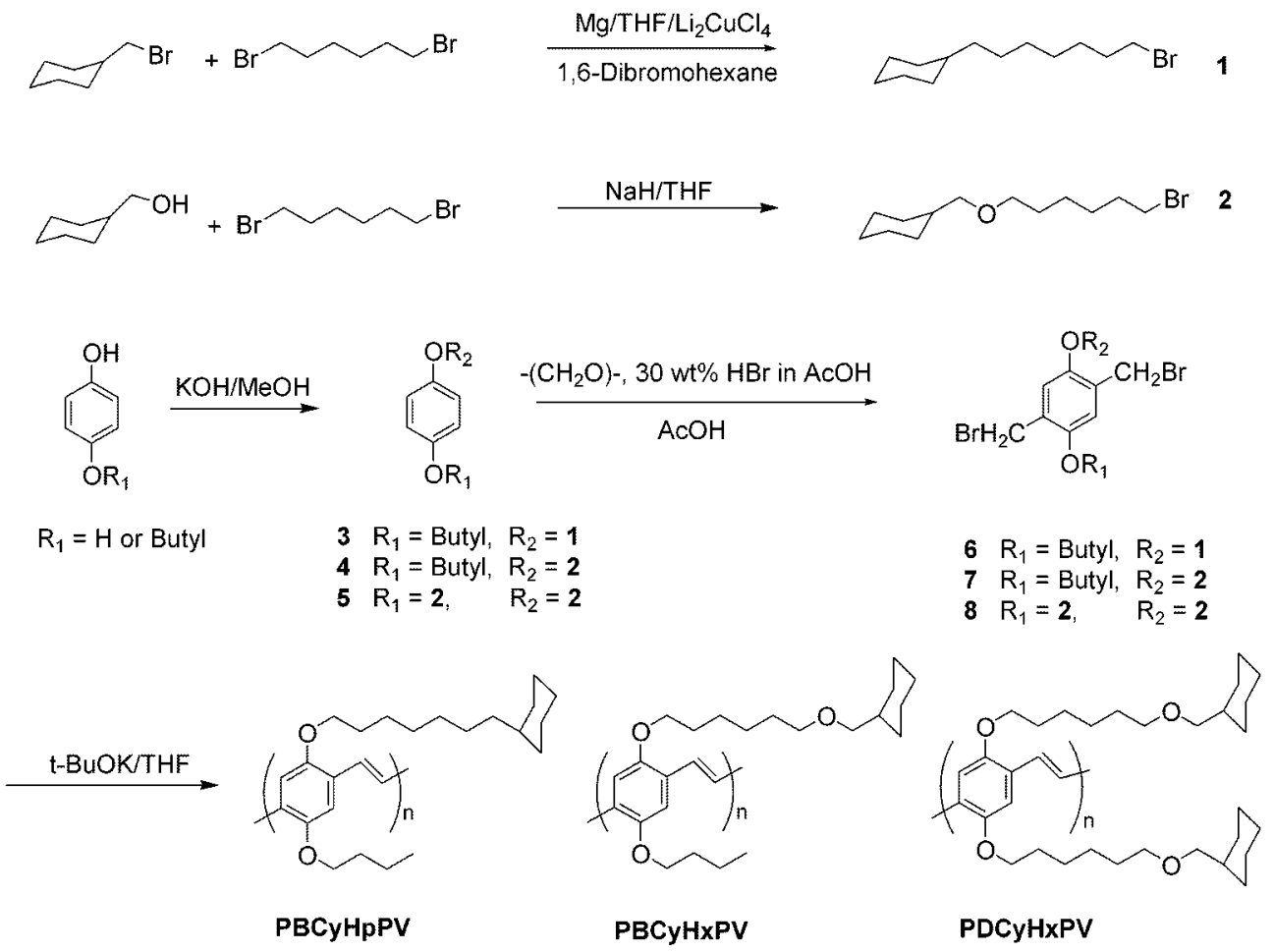

Scheme 1. Synthetic pathways to the monomers and polviners.

was let to procecd for 24 hours at room temperaturc. The completed reaction mixture was slowly added to an excess amount of methanol while stirring it. The crude polymer was precipitated two times in methanol/acctone cosolyent for removal of low-molccular weight products. The polymer yicld was $40 \%$. The synthelic roules and polymer structure are shown in Scheme l. 'H-NMR (CDCl 3. ppm): $\delta 7.48$ (s. 2H). 7.12 (s. 2H). 4.08 (s. 4H). 1.88-0.79 (m. 30H). PDI: 2.33. Mn: 243.000. Mw: 567.000).

Poly[2-(6-cyclohexylmethoxy-hexyloxy)-5-butoxy-1,+phenylenevinylene] PBCyHxPV. The compound 7(1.1 g. 2 mmol) was dissolved in $80 \mathrm{~mL}$ of anlydrous tetralyydrofuran. and $12 \mathrm{~mL}$ of potassium $t$-butoxide ( $1 \mathrm{M}$ in THF) in $60 \mathrm{~mL}$ anhydrous tetrahydrofuran was slowly added dropwise to the solution under nitrogen atmosphere. The following procedures were the same as above described. The polymer vield was $59 \%(0.46 \mathrm{~g}){ }^{1} \mathrm{H}-\mathrm{NMR}\left(\mathrm{CDCl}_{\text {; }}\right.$, ppm): $\delta$ 7.49 (s. 2H). 7.15 (s. 2H). 4.06 (s. $4 \mathrm{H}) .3 .44$ (t. 2H). 3.17 (d. 2H), $1.90-0.80$ (m. 26H). PDI: 3.57. Mn: 174.000. Mn: 622.000 .

Poly|2,5-bis-(6-cyclohexylmethoxy-hexyloxy)-1,4-phenylenevinylene) PDCyHxPV. The compound 8 (1.37 g. 2 mmol) was dissolved in $80 \mathrm{~mL}$ of anhydrous tetralydrofuran. and $12 \mathrm{~mL}$ of potassium $t$-butoxide ( $1 \mathrm{M}$ in THF) in $60 \mathrm{~mL}$ anhydrous tetrahydrofuran was slowly added dropwise to the solution under nitrogen atmosphere. The following procedures were the same as above described. The polymer yield was $52 \%(0.55 \mathrm{~g}) .{ }^{1} \mathrm{H}-\mathrm{NMR}\left(\mathrm{CDCl}_{\text {i. }}\right.$, ppm): $\delta$ 7.47 (s. $2 \mathrm{H}$ ). 7.14 (s. $2 \mathrm{H}$ ). 4.05 (s. $4 \mathrm{H}) .3 .42$ (t. $4 \mathrm{H}) .3 .15$ (d. 4H), $1.90-0.80$ (m. 38H). PDI: 3.29. Mn: 121.000. Mu": 398.000 .

\section{Results and Discussion}

PPV derivalives with bulky cyclohexyl groups as substitucnts. PBCy HpPV. PBCy HxPV and PDCy HxPV. were prepared by the Gilch polymerization with potassium tertbutoxide in THF. The monomer and polymer syntheses are shown in Scheme I. The chemical structures of the three polymers were confirmed by ${ }^{1} H$ NMR. The ${ }^{1} H$ NMR spectra of the polymers in $\mathrm{CDCl}_{3}$ showed viny lene peaks at 7.0-7.1 ppm. but did not contain the bens. lic proton peaks at $4.5-4.6$ ppm of the monomers. All other peaks showed good correspondence with the chemical structures of the polymers. The number-average molecular weights and weight-average molecular weights of the polymers were $121.000-243.000$ and $389.000-622.000$ with a polydispersity of 2.33-3.57, as determined by GPC using THF as eluent and polystyrene as standard.

PBCyHxPV and PDCyHxPV, which have the ether linkage in the side chain, were completely soluble in common organic solvents such as chlorofonn. THF, methy lene chloride. dichloroethane at room temperature. But PBCyHpPV, which has not the ether linkage in the side chaill. showed the selective solubility to some solvents. For examıle. this polymer was completely soluble in chlorofonn and nitrobenzene at room temperature. On the other hand. $\mathrm{PBCr} \mathrm{HpPV}$ was partially soluble at room temperature and conipletely soluble when slightly heated to around $40-60^{\circ} \mathrm{C}$ in xylene. THF and metlylene chloride. The selective solubility of $\mathrm{PBCyHpPV}$ is very useful for the fabrication of multilayer PLEDs without any damages of the polymer layers.

Thermogravimetric analysis (TGA) was performed under 


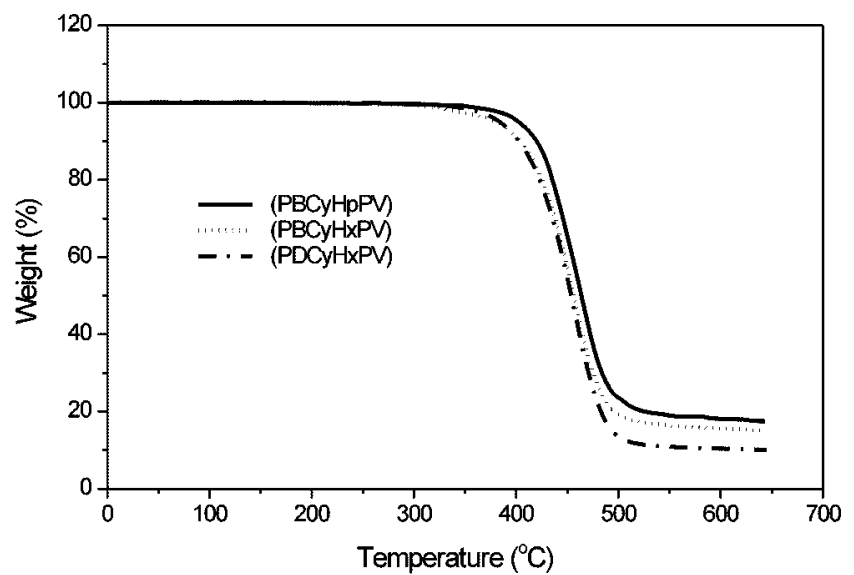

Figure 1. IGA thermograms of PBCyllpPV, PBCyLAPV, and $P L C y l l p l$

nitrogen atmosphere at heating rate of $10{ }^{\circ} \mathrm{C} / \mathrm{min}$. Figure $\mathrm{l}$ shows that the synthesized polymers lose less than $5 \%$ of their weight on heating to $370^{\circ} \mathrm{C}$. This excellent thermal stability of the newly syuthesized polymers can prevent the deformation of the EL cmissive layer from the heat produced during operation of the device.

The thin films of the polymers were prepared on quarly. plates by spin-coating the polymers from their solution in chloroform ( $10 \mathrm{mg}$ polymer/3 $\mathrm{mL}$ solvents). All of the films made from above polymers showed the red color with naked eve. The UV-risible absorption and photoluminescence (PL) spectra of the polymers as thin films are shown in Figure 2. The UV-ris absorption maxima of PBCyHpPV. PBCy $\mathrm{HxPV}$

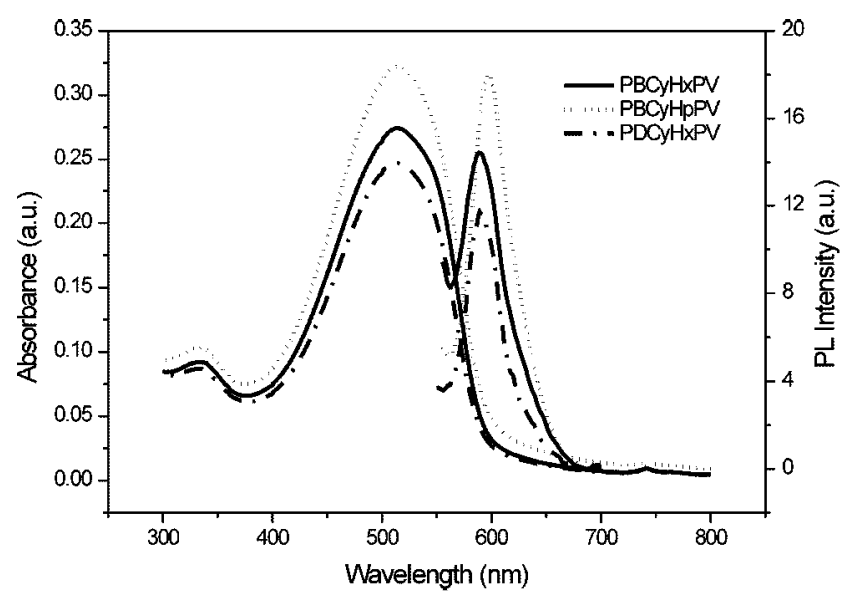

Figure 2. UV-visible absorption and photoluminescence spectra of PBCyllpPV, PBCyIAPV and PDCylpPV.

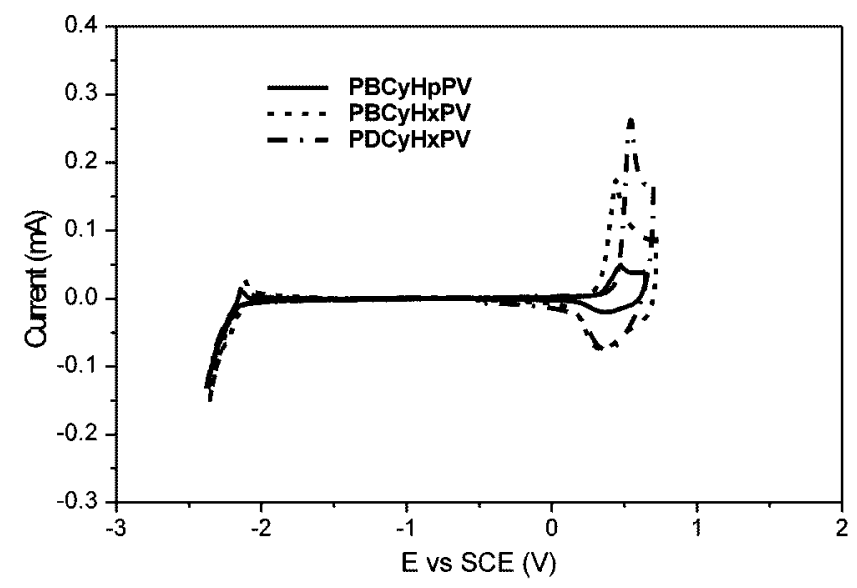

Figure 3. Cyclic volamograms of PBC fllpPV, PBCyllxpV and PDC $\mathrm{YH}$ PPV.

and PDCyHxPV as thin lilms were at $513 \mathrm{~nm}, 515 \mathrm{~nm}, 51 \mathrm{l}$ nm. respectively. PL spectra of PBCyHpPV. PBC, HxPV and PDCyHxPV as thin films showed well-resolved maxima at $590 \mathrm{~nm} .597 \mathrm{~nm}$ and $590 \mathrm{~nm}$, respectively. These PL cmission maxima are similar with those of MEH-PPV and PMCYHPV $^{23}$

Cyclic voltammetry (CV) was cmployed to investigate the redox behavior of the polymers and to estimate their HOMO and LUMO cnergy levels. The polymer films were coated onto a $\mathrm{Pt}$ clectrode and scanned positively and negatively at a scan ratc $50 \mathrm{mV} / \mathrm{s}$ in a $0.1 \mathrm{M}$ solution of tetrabutylammonium tctralluoroboratc $\left(\mathrm{Bu}_{4} \mathrm{NBF}_{4}\right)$ in anly drous acclonitrile. All measurements were calibrated using ferrocene (Fc) as the standard ${ }^{24}$ Figure 3 shows the CV curves of the $p$ - and ndoping processes of the polymers. Both the oxidation and reduction processes of polymers were reversible. In the anodic scan. the onset of oxidation ( $p$-doping) of the polymers occurred around $0.58-0.69 \mathrm{~V}$ ( 1 S SCE). corresponding to HOMO cnergy levels of $-4.97 \sim-5.08 \mathrm{cV}$. On swecping the polymers cathodically; the onsets of reduction ( $n$-doping) began around $-1.72 \sim-1.76 \mathrm{~V}$. corresponding to LUMO energy levels of $2.63 \sim-2.67 \mathrm{eV}$. These HOMO and LUMO energy levels of the polymers are almost sante as the energy levels reported for $\mathrm{MEH}-\mathrm{PPV}^{2}$. The electrochemical data of the polymers obtained from their cyclic voltanmogranns are summarized in Table 1.

Devices with the configuration of ITO/PEDOT/polynier/ $\mathrm{LiF} / \mathrm{Al}$ were fabricated to investigate the electroluninescent properties and the current-voltage-luminance characteristics of the polymers. Polymer films of thickness approximately

Table 1. Llectrochemical properties and energy levels of the polymers

\begin{tabular}{|c|c|c|c|c|c|c|c|c|c|}
\hline \multirow{2}{*}{ Polymer } & \multicolumn{3}{|c|}{$p$-Dopsing $(\mathrm{V})^{a}$} & \multicolumn{3}{|c|}{$n$-Doping $(\mathrm{V})^{a}$} & \multicolumn{3}{|c|}{ Funergy levels (eV) } \\
\hline & $\dot{L}_{\text {inget }}$ & $E_{\mathrm{jar}}$ & $\mathrm{L}_{\mathrm{j}}$ & $E_{\text {intset }}$ & $\mathrm{L}_{\mathrm{jw}}$ & $\mathrm{L}_{\mathrm{j}: \mathrm{l}}$ & $\mathrm{IIOMO}^{\prime \prime}$ & LUMO $^{h}$ & $\mathrm{Lig}_{\mathrm{g}}$ \\
\hline PBCyllpPV & 0.62 & 0.83 & 0.72 & -1.76 & -1.84 & -1.77 & -5.01 & -2.63 & 2.38 \\
\hline PBCyll.pV & 0.58 & 0.80 & 0.51 & -1.72 & -1.78 & -1.88 & -4.97 & -2.67 & 2.30 \\
\hline PDCYIAPV & 0.69 & 0.90 & 0.75 & -1.75 & -1.81 & -1.76 & -5.08 & -2.64 & 2.44 \\
\hline
\end{tabular}

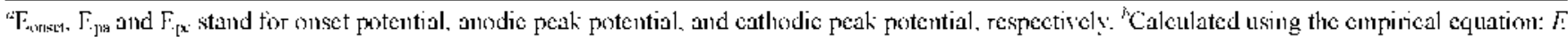
$-\left(\Gamma_{-(3) \operatorname{ser}}-4.39\right)$. 


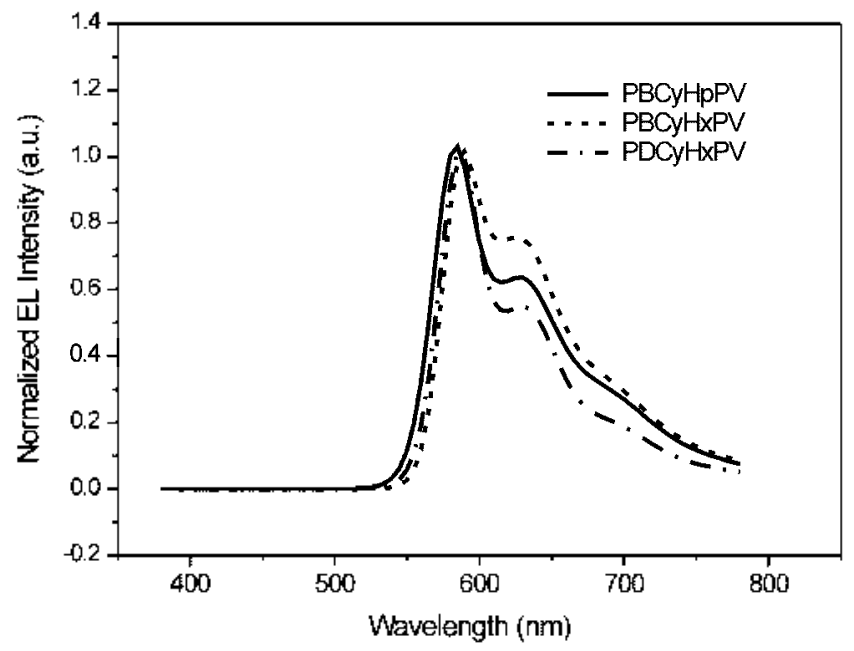

Figure 4. Llectroluminescence spectra of PBCyllpPV, PBCyll.PV

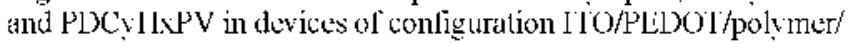
$\mathrm{I} . \mathrm{iF} / \mathrm{N} \mathrm{I}$.

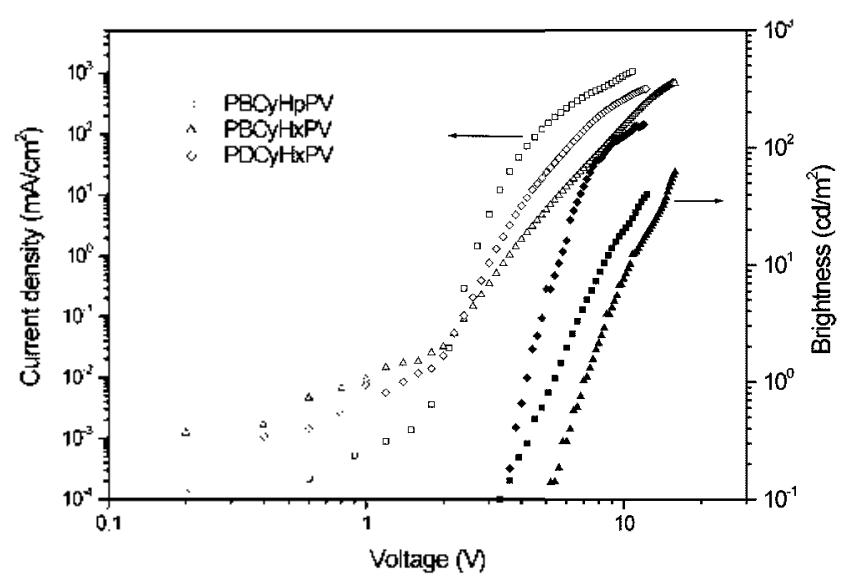

Figure 5. The cument density-voltage and brightness-voltage chatacteristics of PBCYHpPV, PBCSHxPV and PDC H HxP.

$100 \mathrm{rm}$ were spin-coat onto a PEDOT layer of thickness approximately $30 \mathrm{~mm}$. which had been precast on the ITO substrate. The electroluminescence (EL) from the polymers in the devices was orange-red. As shown in Figure 4. the EL spectra of the polymers showed maxima around $585-590$ nun. and shoulder peaks around 630-635 nm. respectively. These features are similar to those observed in the PL spectra of the corresponding polymer films.

The current density-voltage-luminance characteristics ( $I$ $V-L)$ of the devices fabricated from the polymers are shown in Figure 5. In the forward bias, the turn-on voltages $\left(V_{T}\right)$ of the polymers are between 1.7-1.9 V. PL and EL emission peaks, turn-on voltages and EL external quantum efficiencies of the polymers are listed in Table 2. EL emission intensity and efficiency are depending on the substituent stnuctures on the arylene ring and PDCyHxPV shows the lowest turn-on voltage and highest EL external quantum efficiency. These results can be accounted for by the dilution effect of two rigid and bulky cyclohexyl groups in the side chains of PDCyHxPV. This better dilution effect makes
Table 2. Comparison of turn-on voltages and FI, external quantum efticiencies of PBCy HpPV. PBCyHxPV and PDCyHxPV

\begin{tabular}{|c|c|c|c|c|}
\hline Polymer & $\begin{array}{l}\text { PI.FI maximum } \\
\text { (nm) }\end{array}$ & $\begin{array}{l}\text { liunl-on } \\
\text { voliage } \\
\text { (V) }\end{array}$ & $\begin{array}{c}\text { Extcmil } \\
\text { quentum } \\
\text { ellicismey (\%) }\end{array}$ & $\begin{array}{l}\text { Relative } \\
\text { quantums } \\
\text { ellicisncy }\end{array}$ \\
\hline \multirow{2}{*}{\multicolumn{2}{|c|}{ 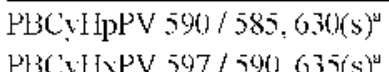 }} & 1.9 & $3.6 \times 10^{3}$ & 1 \\
\hline & & 1.9 & $5.5 \times 10^{3}$ & 1.5 \\
\hline \multicolumn{2}{|c|}{ PLCVHLPV $590 / 590,630(\mathrm{~s})^{4}$} & 1.7 & $1.6 \times 10^{2}$ & 4.4 \\
\hline
\end{tabular}

$(s)^{\mathrm{a}}$ means shoulder peak-

cxcitons created by hole-clectron collision in polymer main chain to undergo radiative pathway rather than non-radiative pathway.

\section{Conclusions}

The new orange-red light-cmitting PPV derivatives containing the rigid and bulky cyclohexyl groups in the side chains. PBCy HpPV. PBCyHxPV and PDCy HxP were synthesized by the Gilch polymerization. A rigid and bulky substitucnt on an ary lene ring is an important factor on the solubility. thermal stability and EL elficiency in the polymer LEDs. $\mathrm{PBCyHpPV}$ showed the selective solubility to the organic solvents. but PBCyHxPV and PDCyHxPV were completely soluble in common organic solvents at room temperature and all of the polymers showed the good thermal stability up to 370 under nitrogen atmosphere. PDCy HxPV showed 4.4 times higher EL cxternal quantum efficiency than that of $\mathrm{PBCy} H \mathrm{pPV}$ due to the dilution effect of two cyclohexyl groups.

Acknowledgment. This work was supported by the Center for Advanced Functional Polymers (CAFPoly) through KOSEF and ILJIN.

\section{References}

I. Burroughes, I. II.: Bradley, J). J). C.: Brown. A. R.: Marks, R. N.: Mackay, K.: Friend. R. II.: I3urn. P. I.: I lolmes, A. B. Notwe (Lomklomi 1990. 347.539.

2. Friend. R. H.: Gymer. R. W.: Holmes. A. B.: Burroughes. J. H.: Marks. R. N.: Tiliani. C.: Bradlcy. D. D. C.: Dos Santos. D. A.: I3redas. I. I... I ögdlund, M : Salaneck. W. Watthe 1999. 397. I2I.

3. Shim, II. K.: Jin. I. I. Adwances in Polymer Scie'te' 2012. 158. 194

4. Yang. Z: Sokolik. I.: Harasz. F. E.: Bradlex: D. D. C. Macronolecules 1993. 26.1188.

5. Sokolik. I.: Yang. Z.: Karasz. F. E. J. tppt Pfw.s. Conmun, 1993. $75, .3584$.

6. ITwang, 1). II. Kang. I. N.: Iang. M. S.: Shim. I I. K. Bull. Konow (Them. Soc. 1995, 16, 1.35

7. Yang. Z.: Karasz. F. E.: Gcise. H. I. Hacromolecules 1993. 26. 6570 .

8. Strukclj. M.: Papadimitrakopoulos. F.: Miller. T. M. Science 1995. $367.196 \%$

9. Grem, G.: I edit/ky, G.: Illrich, B.: I eisitg, G. ids : H/atew 1992. t. 3621 .

10. Berggren. M.: Inganäs. O:- Gustafsson. G.: Carberg. I. C.: Rasmusson. I.: Anderson. M. R.: Hjertherg. T.: Wennerstron. $O$. Nature 1994. 372. 444. 
11. Yoshida. M:: Fujii. A.: Ohmori. Y: Yoshino. K. I. Lppl thys. $1996,35,1.397$

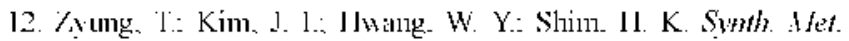
1995, 71, 2167

13. Kang. I. N.: Shim. H. K.: Zyung, T. (Thm. Mattr. 1997. 9. 746

14. Jang. M. S.: Shim. H. K. Potvme Bulletim 1995. 35.49.

15. Shim. H. K.: Jang. M. S.: Hwang. D. H. thacromol Chem. Hhus. 1997, 198,353

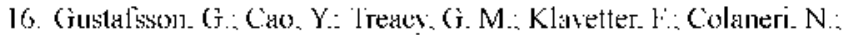
l leeger A. J Nature 1992. $357,477$.

17. Aratani. S.: Zhang. C.: Pakbaz. K.: Hoger. S.: Wudl. F.: Heeger. A. J. J. Elec. Moht 1993. 22.745.

18. Yang. Y: Hecger. A. J. Appl. Hhs Lett. 1994. 64. 1245.

19. 13oi, S: Kuwabaria. M: Noguchi. T: Ohshimo. T. Synth ifet. $1991,55,4174$.
20. Ohshimura. Y.: Uehida. M.: Muro. K: Yoshino, K. $f p h$. f. ilppl. thes $1991,30,1,1938$

21. Anderson. M. R.: Jerggerren. M.: Ingandis, O.: Gustalisson, G.: (justal'sson-Carlsherg, J. C.: Selse. I): I ljetberg, I: Wennerstorm. O. Hacromokeculs 1995. 28.7526.

22. Inganäs. O.: Bergecrren. M.: Anderson. M. R.: Gustatsson. G.: Hjertbere. T: Wennerstom. O: Drreklev. P:: Granstrom. M. Synth lifet 1995. 7l. 2121 .

23. Jang. M. S.: Song S. Y.: I,ee, I. I.: Shim. II. K.: \% Y ung I Macronol. Ghem. Plons. 1999. 200, 1101.

24. Pommerehe. J.: Vestweber. H.: Guss. W.: Mahrt. R. F.: Büssler. H.: Porsch. M.: Daub. J. A A k. Matur. 1995. 7. 55.

25. Ahn. T.: Ko. S. W. Le. J.: Shim. H. K. Hacromolecules 2002. 35. 3495 